Article

\title{
Hydrogen and Oxygen Evolution in a Membrane Photoreactor Using Suspended Nanosized $\mathrm{Au} / \mathrm{TiO}_{2}$ and $\mathrm{Au} / \mathrm{CeO}_{2}$
}

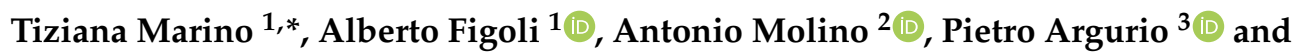 \\ Raffaele Molinari ${ }^{3, * \mathbb{D}}$ \\ 1 Institute on Membrane Technology (ITM), National Research Council of Italy (CNR), Via P. Bucci Cubo 17C, \\ I-87036 Rende (CS), Italy; a.figoli@itm.cnr.it \\ 2 Research Centre of Portici, Italian National Agency for New Technologies, Energy and Sustainable Economic \\ Development (ENEA), Piazzale Enrico Fermi 1, Portici, 80055 Napoli, Italy; antonio.molino@enea.it \\ 3 Department of Environmental and Chemical Engineering, University of Calabria, Via P. Bucci, 44/A, \\ I-87036 Rende (CS), Italy; pietro.argurio@unical.it \\ * Correspondence: t.marino@itm.cnr.it (T.M.); raffaele.molinari@unical.it (R.M.)
}

Received: 8 October 2018; Accepted: 4 January 2019; Published: 10 January 2019

\begin{abstract}
Photocatalysis combined with membrane technology could offer an enormous potential for power generation in a renewable and sustainable way. Herein, we describe the one-step hydrogen and oxygen evolution through a photocatalytic membrane reactor. Experimental tests were carried out by means of a two-compartment cell in which a modified Nafion membrane separated the oxygen and hydrogen evolution semi-cells, while iron ions permeating through the membrane acted as a redox mediator. Nanosized $\mathrm{Au} / \mathrm{TiO}_{2}$ and $\mathrm{Au} / \mathrm{CeO}_{2}$ were employed as suspended photocatalysts for hydrogen and oxygen generation, respectively. The influence of initial $\mathrm{Fe}^{3+}$ ion concentration, ranging from 5 to $20 \mathrm{mM}$, was investigated, and the best results in terms of hydrogen and oxygen evolution were registered by working with $5 \mathrm{mM} \mathrm{Fe}^{3+}$. The positive effect of gold on the overall water splitting was confirmed by comparing the photocatalytic results obtained with the modified/unmodified titania and ceria. Au-loading played a key role for controlling the photocatalytic activity, and the optimal percentage for hydrogen and oxygen generation was $0.25 \mathrm{wt} \%$. Under irradiation with visible light, hydrogen and oxygen were produced in stoichiometric amounts. The crucial role of the couple $\mathrm{Fe}^{3+} / \mathrm{Fe}^{2+}$ and of the membrane on the performance of the overall photocatalytic system was found.
\end{abstract}

Keywords: water splitting; Z-scheme; photocatalysis; photocatalytic membrane reactor

\section{Introduction}

Photocatalytic water splitting to generate hydrogen from solar light is a process that can play an important role for the future development of clean and renewable energies alternative to fossil fuels [1-8]. The combination of photocatalysis, which allows converting solar energy into chemical energy, and membrane-based operations could offer the possibility to achieve one-step hydrogen generation from water splitting at ambient temperature without needing further energy inputs. Hydrogen attracted increasing interest as a valid candidate for fossil-fuel substitution, enough to give rise to create the so-called "hydrogen economy" in 1970 [9-12].

From a thermodynamic point of view, hydrogen oxidation can offer three times the energy per gram in comparison to fossil fuels as gasoline. Moreover, hydrogen oxidation leads to the formation of water, making it a zero-emission fuel. Hydrogen also finds applications in the chemical industry as a reagent in fine-chemical synthesis [12]. 
Since Fujishima and Honda discovered photocatalytic water splitting by means of $\mathrm{TiO}_{2}$ electrodes in 1972 [13], noticeable works were carried out in order to investigate photocatalytic-based hydrogen generation from water via both photocatalysis and photoelectrochemistry [14]. Particular attention was paid to semiconductor oxides, due to their simple preparation through calcination and their stability toward oxygen generation [15-19]. The water-splitting pathway involves a series of radical reactions initiated by light-driven photocatalyst activation, as deeply described in the literature [3].

Among the well-known semiconductors, nanosized $\mathrm{TiO}_{2}$ is attracting more and more interest, due to its unique properties of physico-chemical stability and inertness, low cost, biocompatibility, durability, long-term photo-stability, and potent oxidative power under ultraviolet (UV)-light irradiation [20-22]. Despite its numerous advantages, the use of $\mathrm{TiO}_{2}$ still presents a limitation, i.e., only UV light, representing $\sim 4 \%$ of total solar energy, can be absorbed by titania nanoparticles. Therefore, extending $\mathrm{TiO}_{2}$ light absorption to the visible fraction represents a challenging target for photocatalysis applications. Various techniques, such as noble-metal and non-metal doping, dye sensitization, and coupling with carbon materials were adopted in order to modify the electronic band of titania [23].

In a previous work, we reported that gold nanoparticles supported on titania $\left(\mathrm{Au} / \mathrm{TiO}_{2}\right)$ represent a suitable photocatalyst for the generation of hydrogen with visible light using methanol and ethylenediaminetetraacetic acid (EDTA) as sacrificial electron donors [14]. A remarkable overall efficiency of approximately 5\% measured at $560 \mathrm{~nm}$ was determined [14]. In this system, gold nanoparticles act as a durable and stable photosensitizer, absorbing visible light and injecting electrons in the conduction band of the $\mathrm{TiO}_{2}$. Using $0.25 \mathrm{wt} \%$ gold loading on titania and methanol as a sacrificial agent, $\sim 98 \mu \mathrm{mol}$ of hydrogen was obtained (catalyst content $2 \mathrm{~g} / \mathrm{L}$ ) after $4 \mathrm{~h}$ of irradiation with visible light [14].

Also, we showed that ceria of small average particle size can behave as a semiconductor with a remarkably high efficiency for the photocatalytic generation of oxygen from water using $\mathrm{Ag}^{+}$or $\mathrm{Ce}^{3+}$ as a sacrificial electron acceptor [24]. The best performing $\mathrm{CeO}_{2}$ sample was that prepared using a biopolymer "alginate" as a templating agent to synthesize about $5 \mathrm{~nm}$ of average particle size with a Brunauer-Emmett-Teller (BET) surface area of $93 \mathrm{~m}^{2} \cdot \mathrm{g}^{-1}$ [24]. Also, in this case, visible-light photocatalytic activity was implemented by depositing gold nanoparticles on $\mathrm{CeO}_{2}\left(\mathrm{Au} / \mathrm{CeO}_{2}\right)$, which allowed achieving $~ 50 \mu \mathrm{mol}$ of oxygen when the aqueous suspension containing $0.25 \mathrm{wt} \%$ gold deposited on $\mathrm{CeO}_{2}$ was irradiated for $4 \mathrm{~h}$ with visible light in the presence of $\mathrm{AgNO}_{3}$ as a sacrificial agent [24].

Considering the above precedents and the visible-light photocatalytic activity for independent hydrogen and oxygen generation using $\mathrm{Au} / \mathrm{TiO}_{2}$ or $\mathrm{Au} / \mathrm{CeO}_{2}$, respectively, in the presence of an appropriate sacrificial agent, it occurs that these two photocatalysts could also work in a system to perform the simultaneous generation of hydrogen and oxygen in the absence of sacrificial agents using a Z-scheme [25-28]. In this Z-scheme methodology, hydrogen and oxygen are generated photocatalytically in different cells that are irradiated and separated by a membrane [5,29-34]. An electrolyte is used to ensure the electroneutrality in each cell and to allow charge transfer from one compartment to the other.

Li et al. [5] reported concomitant hydrogen generation and phenol degradation in a photocatalytic twin reactor under simulated solar light. In the proposed system, $\mathrm{Pt} / \mathrm{STO}: \mathrm{Rh}$ was used as a photocatalyst for hydrogen evolution, while $\mathrm{WO}_{3}$ was chosen for phenol oxidation. A Nafion membrane separated the two compartments of the cell. $\mathrm{Fe}^{3+} / \mathrm{Fe}^{2+}$ pairs were used for electron transfer. The obtained data evidenced a hydrogen generation rate of $1.90 \mu \mathrm{mol} \cdot \mathrm{g}^{-1} \cdot \mathrm{h}^{-1}$. Moreover, by employing a phenol initial concentration of $200 \mu \mathrm{mol} \cdot \mathrm{L}^{-1}$, hydrogen yield reached a value of $11.37 \mu \mathrm{mol} \cdot \mathrm{g}^{-1}$ after $6 \mathrm{~h}$ of irradiation, corresponding to an increase of $20 \%$ compared to that of pure water splitting. Fujihara et al. [35] studied water splitting in a two-compartment cell using $\mathrm{Pt} / \mathrm{TiO}_{2}$-anatase as a catalyst for hydrogen generation suspended in $\mathrm{Br}_{2} / \mathrm{Br}^{-}$aqueous solution and $\mathrm{Pt} / \mathrm{TiO}_{2}$-rutile for simultaneous oxygen evolution in an $\mathrm{Fe}^{3+} / \mathrm{Fe}^{2+}$ redox couple solution. Yu et al. [33] 
also reported the experimentation of a twin reactor for the synchronized formation of hydrogen, through the photocatalytic activity of $\mathrm{BiVO}_{4}$, and oxygen using $\mathrm{Pt} / \mathrm{SrTiO}_{3}: \mathrm{Rh}$. A Nafion membrane was inserted in the two-side system to assure the separate generation of the two gases. Similarly to the above mentioned works, the $\mathrm{Fe}^{3+} / \mathrm{Fe}^{2+}$ redox couple was also selected in this case as a redox mediator.

Hydrogen and oxygen in a stoichiometric ratio (2:1) were obtained, with a maximum hydrogen formation rate of $0.65 \mu \mathrm{mol} \cdot \mathrm{g}^{-1} \cdot \mathrm{h}^{-1}$. Lo et al. [31] investigated the water-splitting process for the one-step $\mathrm{H}_{2}$ and $\mathrm{O}_{2}$ generation by means of a membrane twin reactor under visible-light irradiation. $\mathrm{Pt} / \mathrm{SrTiO}_{3}: \mathrm{Rh}$ and $\mathrm{WO}_{3}$ were designated as hydrogen- and oxygen-evolution semiconductors, respectively. The formation of the two gases reflected their stoichiometric ratio, with an average hydrogen evolution rate equal to $1.59 \mu \mathrm{mol} \cdot \mathrm{g}^{-1} \cdot \mathrm{h}^{-1}$.

Nafion represents a valid choice as a membrane material, since it is characterized by outstanding chemical and physical resistance [36] and an affinity for iron species. Ramirez et al. [37] investigated the uptake characteristics of different cations $\left(\mathrm{Fe}^{3+}, \mathrm{Cu}^{2+}\right.$, and $\left.\mathrm{Ni}^{2+}\right)$ by Nafion 117 , which is commonly used as a separator for different chemical processes. The membrane exhibits its affinity in the order $\mathrm{Fe}^{3+} \geq \mathrm{Ni}^{2+} \geq \mathrm{Cu}^{2+}$, similar to that reported in a previous study [38]. In another study [39], it was reported that a Nafion/Fe membrane was resistant to the attack of the highly oxidative radical $\bullet \mathrm{OH}$ $\left(\mathrm{E}^{\circ} \bullet \mathrm{OH} /-\mathrm{OH}=1.90 \mathrm{eV}\right.$ vs. normal hydrogen electrode (NHE)) and did not allow leaching of the Fe exchanged on the sulfonic groups within the 3000-h testing period. Kiwi et al. [40] demonstrated that iron compounds supported on a Nafion membrane gave good results in a photo-Fenton water treatment process, where the Fe ions were fixed and remained active in $\mathrm{H}_{2} \mathrm{O}_{2}$ decomposition.

In the present work, we studied the overall photocatalytic water splitting using Au nanoparticles as a sensitizer of $\mathrm{TiO}_{2}$ and $\mathrm{CeO}_{2}$ semiconductors irradiated with visible light in combination, a Nafion film as a membrane separating two cells, and ferric sulfate as the electrolyte. Diffusion tests on the iron-modified Nafion membrane were performed to determine its ability to allow diffusion of iron species. The influence on system performance of initial $\mathrm{Fe}^{3+}$ concentration and of Au loading on the $\mathrm{O}_{2}$ and $\mathrm{H}_{2}$ evolution photocatalysts was determined. Finally, the photocatalytic activity of the pairs $\left(\mathrm{Au} / \mathrm{TiO}_{2}\right.$ and $\left.\mathrm{Au} / \mathrm{CeO}_{2}\right)$ for the photocatalytic water splitting through a Z-scheme under visible light was demonstrated.

\section{Materials and Methods}

$\mathrm{TiO}_{2}$ (particle size: $20 \mathrm{~nm}$; rutile/anatase: 85:15, 99.9\%) was a commercial P25 sample supplied by Degussa. $\mathrm{CeO}_{2}$ was prepared starting from an aqueous solution of alginate that was flocculated with cerium nitrate followed by calcination as previously reported [24]. Gold nanoparticles were deposited on $\mathrm{TiO}_{2}$ and $\mathrm{CeO}_{2}$ via the deposition-precipitation method starting from $\mathrm{AuHCl}_{4}$ and maintaining $\mathrm{pH}=10$ as described in Reference [14]. TEM images were recorded with a Jeol $200 \mathrm{Cx}$ microscope operating at $200 \mathrm{kV}$.

\subsection{Photocataytic Tests}

The photocatalytic membrane reactors (PMRs) experimented in the present work for simultaneous generation of hydrogen and oxygen from water splitting mimic the Z-scheme mechanism used by plants for natural photosynthesis. The Z-scheme (Figure 1a) basically includes two photocatalysts: (i) the oxygen evolution photocatalyst $\left(\mathrm{Au} / \mathrm{CeO}_{2}\right.$ in this study) leading to $\mathrm{O}_{2}$ formation via water oxidation, and (ii) the hydrogen evolution photocatalyst $\left(\mathrm{Au} / \mathrm{TiO}_{2}\right.$ in this study) which promotes $\mathrm{H}_{2}$ formation via water reduction. The aqueous suspensions containing the two photocatalysts need to be separated by a membrane able to transports electrons via a redox couple $\left(\mathrm{Fe}^{3+} / \mathrm{Fe}^{2+}\right.$ in this study) acting as an electron redox mediator.

The experimental set-up (Figure 1b) consisted of a two-compartment Pyrex cell, each with a volume of $50 \mathrm{~mL}$, separated by a Nafion modified membrane with an exposed membrane surface area of $3.14 \mathrm{~cm}^{2}$. Each compartment, containing $60 \mathrm{mg}$ of photocatalyst suspended in $30 \mathrm{~mL}$ of Milli-Q water (corresponding to $2 \mathrm{~g} \cdot \mathrm{L}^{-1}$ photocatalyst concentration), was irradiated with a $125-\mathrm{W}$ 
medium-pressure mercury lamp (DLU, HDLM E27) equipped with a Pyrex glass jacket which allows maintaining the system at a temperature of $20^{\circ} \mathrm{C}$. The suspensions were purged with argon flow for at least $30 \mathrm{~min}$ before irradiation in order to remove dissolved air. For polychromatic visible-light irradiation, an $\mathrm{Fe}_{2}\left(\mathrm{SO}_{4}\right)_{3}$ solution $(3 \% w / v)$, circulated into the Pyrex glass jacket of the lamp, was used as a cut-off filter $(\lambda>400 \mathrm{~nm})$. Hydrogen and oxygen generation was determined by injecting $0.1 \mathrm{~mL}$ of each Pyrex cell headspace gas in a gas chromatograph (GC; Agilent 7890A) equipped with a thermal conductivity detector. The GC determination was carried out by operating in isothermal conditions $\left(50{ }^{\circ} \mathrm{C}\right)$, with a capillary column (CP-PoraPLOT Q, molecular sieve, $530 \mu \mathrm{m}$ inner diameter, $15 \mathrm{~m}$ length) and argon as a carrier gas.

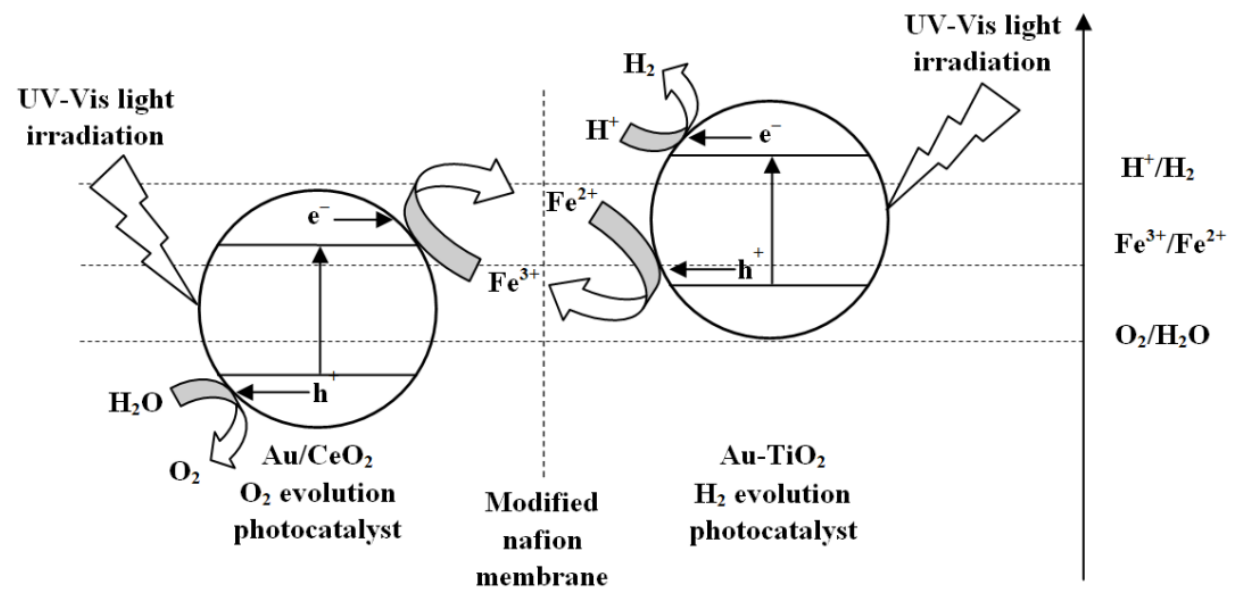

(a)

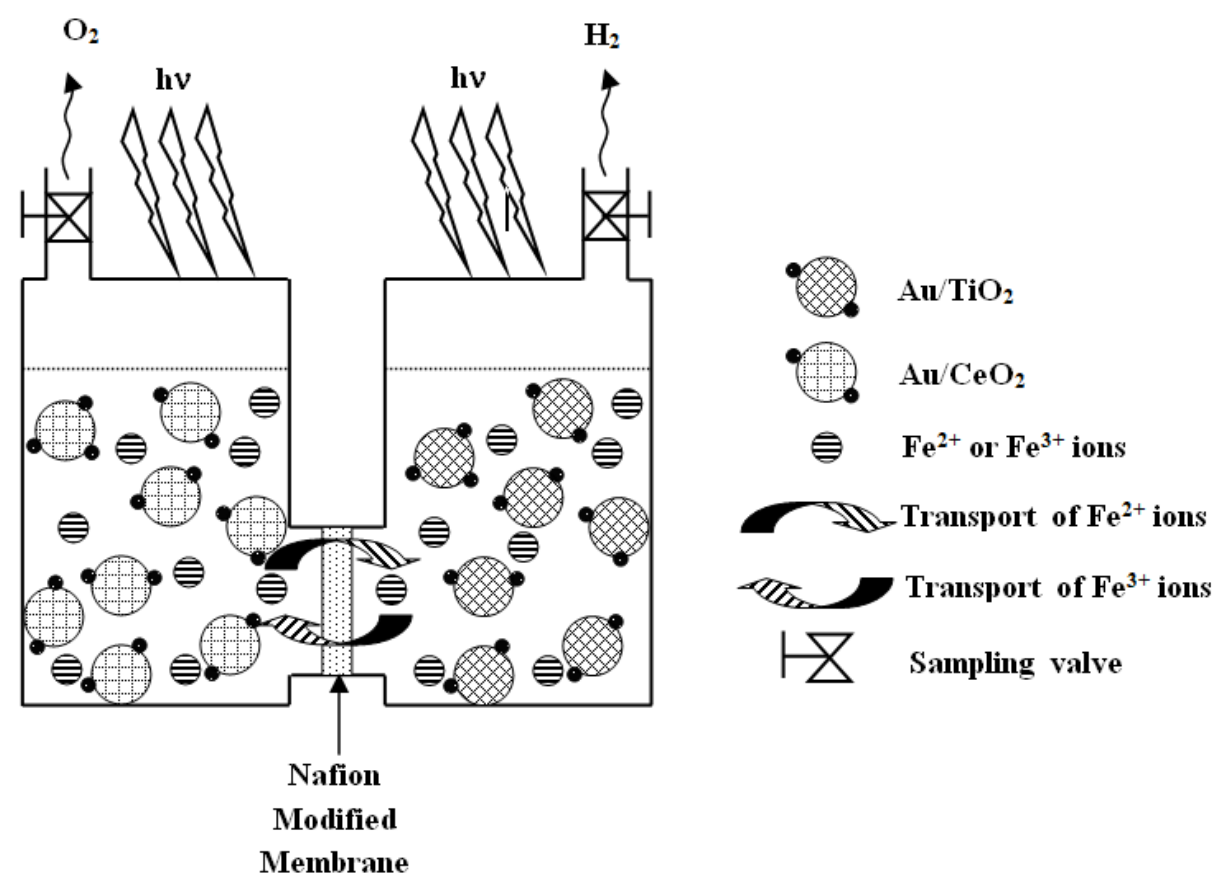

(b)

Figure 1. (a) Diagram of the Z-scheme overall water splitting using $\mathrm{Au} / \mathrm{CeO}_{2}$ as a photocatalyst for oxygen generation, $\mathrm{Au} / \mathrm{TiO}_{2}$ for hydrogen generation, and $\mathrm{Fe}^{3+} / \mathrm{Fe}^{2+}$ as a redox couple. (b) Conceptual scheme of the set-up used for photocatalytic experiments. 


\subsection{Membrane Modification}

The Nafion 117 membrane (Aldrich, thickness of $178 \mu \mathrm{m}$ ) was modified using the procedure described herein before its use. In the first step, the membrane was boiled in a $1 \mathrm{M} \mathrm{HNO}_{3}$ solution for $2 \mathrm{~h}$ to remove any contaminant; then, it was washed with Milli-Q water, immersed in a $1 \mathrm{M} \mathrm{NaOH}$ solution, and subsequently in a $1 \mathrm{M} \mathrm{H}_{2} \mathrm{SO}_{4}$ solution for $4 \mathrm{~h}$, each for conditioning the membrane [41]. Finally, the Nafion membrane was immersed in a $0.5 \mathrm{M} \mathrm{Fe}_{2}\left(\mathrm{SO}_{4}\right)_{3}$ solution for $24 \mathrm{~h}$ to change its functional groups $\left(\mathrm{H}^{+}\right)$with $\mathrm{Fe}^{3+}$ ions.

\subsection{Iron Spectrophotometric Determination}

Spectrophotometric analyses were performed using 1,10-phenanthroline (Fluka, Aquanal Plus kit) and potassium thiocyanate (Aldrich), for total iron $(\lambda=510 \mathrm{~nm})$ and ferric ion $(\lambda=477 \mathrm{~nm})$ determinations, respectively. Ferrous iron ion concentration present in solution was calculated by the difference between total and ferric iron concentration.

\section{Results and Discussion}

\subsection{Diffusion Test}

The iron-containing modified Nafion membrane was tested to determine its ability to allow diffusion of iron species. Similar concentrations of $\mathrm{Fe}^{2+}$ and $\mathrm{Fe}^{3+}$ as that utilized in the photocatalytic experiments were used in one compartment and, then, the presence of corresponding iron species over time was determined in the other compartment. The corresponding profiles of iron species diffusing through the membrane are provided in Figure 2.

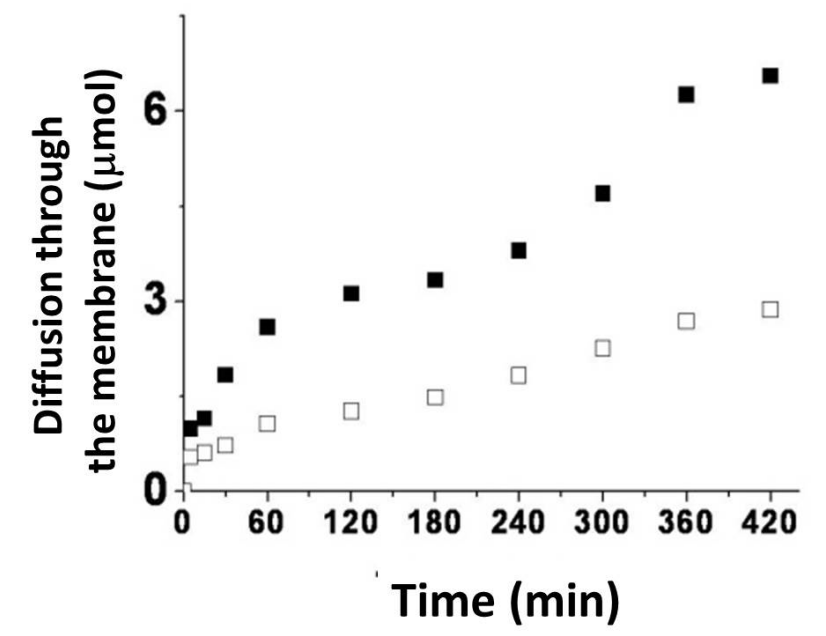

Figure 2. $\mathrm{Fe}^{2+}(\square)$ and $\mathrm{Fe}^{3+}(\square)$ transport over time through the Nafion membrane in the compartment cell with no initial salt.

It was observed that, while $\mathrm{Fe}^{3+}$ diffusion could be fitted by a straight line, i.e., the concentration of $\mathrm{Fe}^{3+}$ in the chamber without it grew linearly over time, similar experiments with $\mathrm{Fe}^{2+}$ salt clearly revealed two regimes. These results might be explained considering that, in the first regime, ion exchange of $\mathrm{Fe}^{3+}$ and $\mathrm{Fe}^{2+}$ occurred in the Nafion membrane concomitantly to the diffusion. In the second regime, the Nafion membrane behaved essentially as a Fe${ }^{2+}$ exchanger.

The iron content in the membrane before and after its use was estimated by SEM energy dispersive X-ray spectroscopy (EDX) analysis. The results showed an iron weight loading of $\sim 1.3 \%$ and this value did not change after using the membrane (Figure 3). 

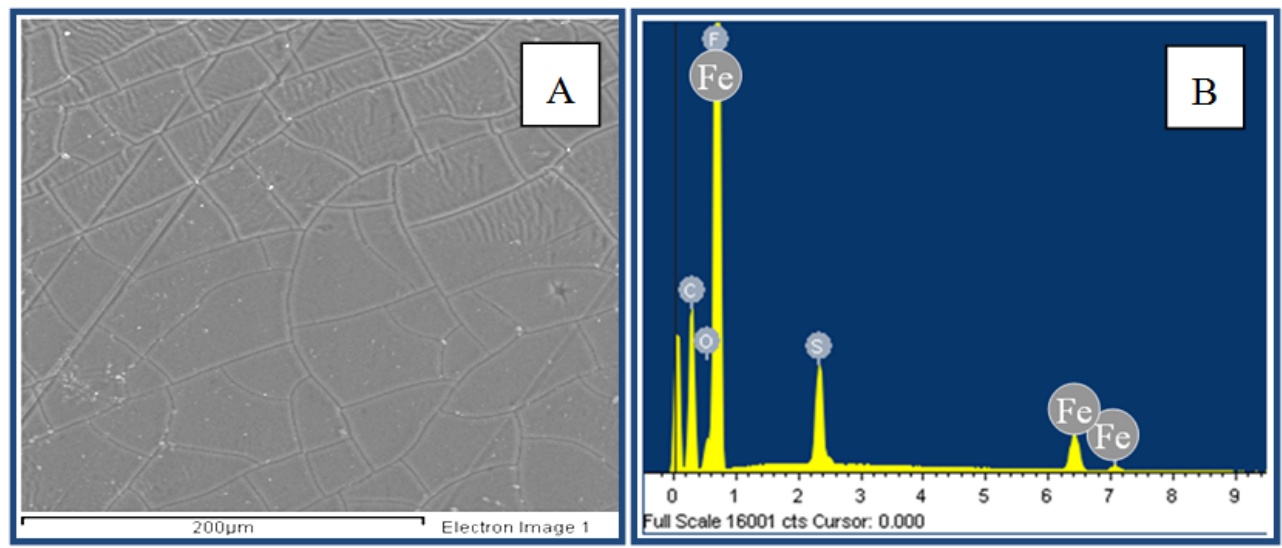

Figure 3. SEM picture of Nafion membrane used for the photocatalytic test (A) and energy-dispersive X-ray spectroscopy (EDX) analysis of ferric ion-modified membrane (B).

Figure 4 reports TEM pictures of the $\mathrm{Au} / \mathrm{TiO}_{2}$ and $\mathrm{Au} / \mathrm{CeO}_{2}$ photocatalysts. The average particle size of photocatalyst nanoparticles, determined by considering a statistically relevant number of particles in the TEM images of the samples, resulted in 2.7 and $5.0 \mathrm{~nm}$ for $\mathrm{Au} / \mathrm{TiO}_{2}$ and $\mathrm{Au} / \mathrm{CeO}_{2}$, respectively.
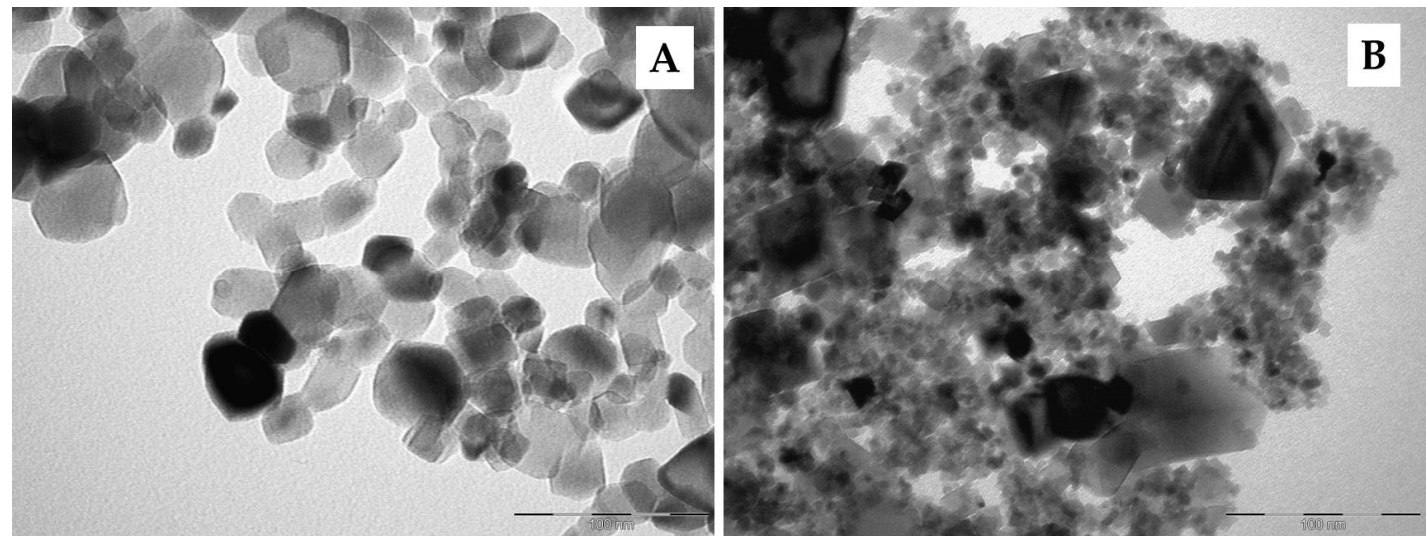

Figure 4. TEM images of $\mathrm{Au} / \mathrm{TiO}_{2}(\mathbf{A})$ and $\mathrm{Au} / \mathrm{CeO}_{2}$ (B).

\subsection{Photocatalytic Tests}

For the irradiation of the suspensions, a 125-W medium-pressure mercury lamp was used. This lamp exhibited emission peaks at a discrete wavelength, mostly in the visible region (total irradiation $2133 \mathrm{~mW} / \mathrm{m}^{2}$ with $61 \%$ in the visible range). The inset of Figure 5 shows the emission peaks in the spectrum of the lamp used.

Preliminary photocatalytic tests were carried out evidencing the crucial role of the couple $\mathrm{Fe}^{3+} / \mathrm{Fe}^{2+}$ on both hydrogen and oxygen generation. Indeed, by starting the working of the cell with $\mathrm{Fe}^{2+}$ ions in the cell containing $\mathrm{Au} / \mathrm{TiO}_{2}$ and $\mathrm{Fe}^{3+}$ ions in the cell containing $\mathrm{Au} / \mathrm{CeO}_{2}$, oxygen generation in both cells was observed during the first $30 \mathrm{~min}$. We suggest that the reason why oxygen was generated in $\mathrm{Au} / \mathrm{TiO}_{2}$ cell instead of the expected hydrogen was because $\mathrm{Fe}^{3+}$ was formed by $\mathrm{Fe}^{2+}$ oxidation, in the presence of oxygen by air, during the preparation of the work-up cell. Analysis of the $\mathrm{Fe}^{3+}$ concentration in the $\mathrm{Au} / \mathrm{TiO}_{2}$ cell confirmed that about $22 \%$ of $\mathrm{Fe}^{2+}$ ions were oxidized to $\mathrm{Fe}^{3+}$ during this stage. The formed $\mathrm{Fe}^{3+}$ quenched the generation of hydrogen and promoted the formation of oxygen, owing to the preferential reduction of $\mathrm{Fe}^{3+}$ by photogenerated electrons with respect to the photoreduction of water. As a consequence, during the first $30 \mathrm{~min}$, oxygen generation (instead of hydrogen) was observed into the $\mathrm{Au} / \mathrm{TiO}_{2}$ cell before changing to continuous hydrogen generation. 
On the basis of these preliminary results, to avoid the presence of $\mathrm{Fe}^{3+}$ ions in the $\mathrm{Au} / \mathrm{TiO}_{2}$ cell, the iron ions were initially added to the system only in the form of $\mathrm{Fe}^{3+}$ at different concentrations, as reported in Table 1, in the cell containing $\mathrm{Au} / \mathrm{CeO}_{2}$, while, in the $\mathrm{Au} / \mathrm{TiO}_{2}$ cell, the initial iron concentration was zero. Figure 5 shows the temporal evolution of hydrogen in the $\mathrm{Au}(0.25 \mathrm{wt} \%) / \mathrm{TiO}_{2}$ cell and oxygen in the $\mathrm{Au}(0.25 \mathrm{wt} \%) / \mathrm{CeO}_{2}$ cell when $5 \mathrm{mM} \mathrm{Fe}^{3+}$ was added in the $\mathrm{Au} / \mathrm{CeO}_{2}$ cell. Operating under these conditions, the reaction started on $\mathrm{Au} / \mathrm{CeO}_{2}$ with oxygen evolution via water oxidation coupled with the reduction of $\mathrm{Fe}^{3+}$ to $\mathrm{Fe}^{2+}$. The so-produced $\mathrm{Fe}^{2+}$ ions permeated across the Nafion modified membrane starting hydrogen evolution in the $\mathrm{Au} / \mathrm{TiO}_{2}$ compartment. As a consequence, during this early stage of the reaction (approximately $5 \mathrm{~min}$ ), the ratio $\mathrm{H}_{2}: \mathrm{O}_{2}$ was about 1:1 (see Figure 5) and evidenced that $\mathrm{H}_{2}$ generation was promoted by $\mathrm{Fe}^{2+}$ which permeated through the membrane. After this initial stage, two regimes can be observed: a first one, until $60 \mathrm{~min}$, and a second one, from 60 to $300 \mathrm{~min}$. This trend can be explained considering that, in Figure 2, a similar trend with the same two regimes can be observed for $\mathrm{Fe}^{2+}$ permeation through the membrane. It could be deduced that $\mathrm{Fe}^{2+}$ ion diffusion during the first regime was faster than that during the second regime ( 0.043 vs. $0.022 \mu \mathrm{mol}_{\mathrm{Fe}}{ }^{2+} \mathrm{min}^{-1}$ ) and this behavior affected the photocatalytic reaction. Indeed, the $\mathrm{Fe}^{2+}$ ions produced in the $\mathrm{Au} / \mathrm{CeO}_{2}$ cell permeated across the membrane and promoted a generation of hydrogen in the $\mathrm{Au} / \mathrm{TiO}_{2}$ cell. After $300 \mathrm{~min}$, a very low hydrogen production was detected, probably because of the negligible permeation of $\mathrm{Fe}^{2+}$ ions across the membrane (see Figure 2) which blocked the Z-scheme mechanism. However, it should be observed that both photocatalysts efficiently worked during these two regimes (slopes of $1.25 \mu \mathrm{mol}_{\mathrm{H} 2} \cdot \mathrm{min}^{-1}$ during the first regime and $0.41 \mu \mathrm{mol}_{\mathrm{H} 2} \cdot \mathrm{min}^{-1}$ during the second regime), promoting the simultaneous generation of hydrogen and oxygen in a stoichiometric amount in the $\mathrm{Au} / \mathrm{TiO}_{2}$ and $\mathrm{Au} / \mathrm{CeO}_{2}$ cells, respectively, and that blocking was only caused by $\mathrm{Fe}^{2+}$ ion permeation through the membrane.

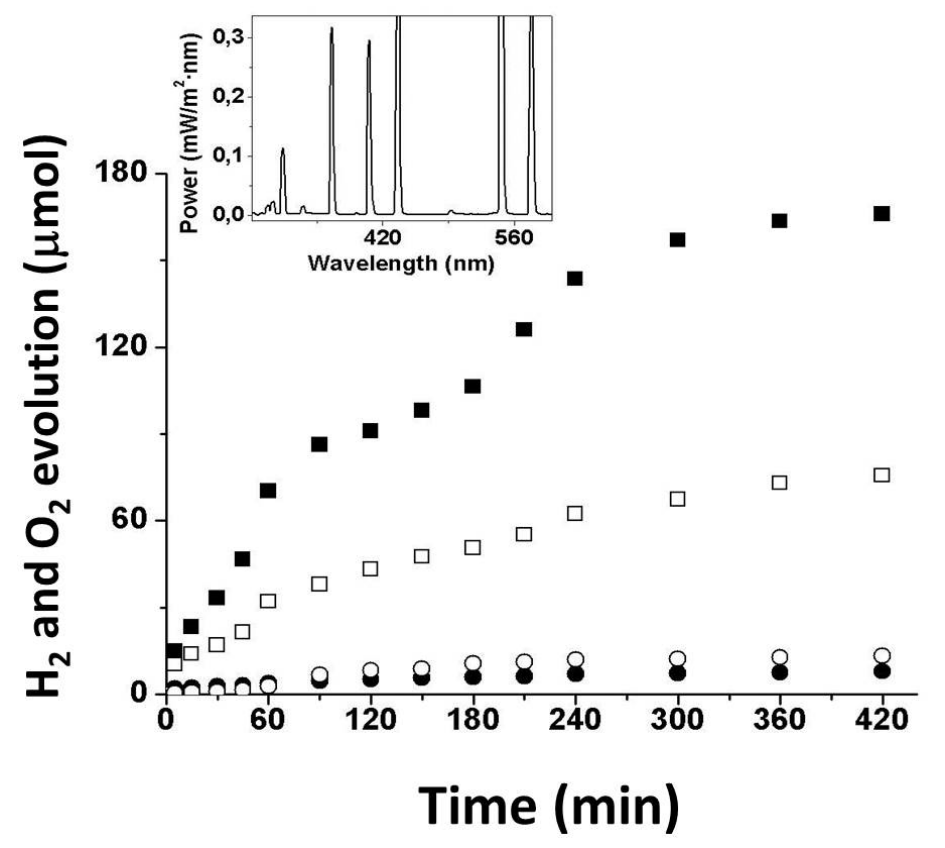

Figure 5. Hydrogen production ( $\square$ ) using $\mathrm{Au}(0.25 \mathrm{wt} \%) / \mathrm{TiO}_{2}$ and oxygen production $(\square)$ using $\mathrm{Au}$ $(0.25 \mathrm{wt} \%) / \mathrm{CeO}_{2}$ compared with hydrogen production $(\bullet)$ using $\mathrm{TiO}_{2}$ and oxygen production $(\bigcirc)$ using $\mathrm{CeO}_{2}$ only (initial $\mathrm{Fe}^{3+}$ concentration was $5 \mathrm{mM}$ in the $\mathrm{Au} / \mathrm{CeO}_{2}$ cell and initial $\mathrm{Fe}^{2+}$ concentration was zero in the $\mathrm{Au} / \mathrm{TiO}_{2}$ cell).

The initial concentration of $\mathrm{Fe}^{3+}$ ions in the $\mathrm{Au} / \mathrm{CeO}_{2}$ cell varied in the range from 2 to $50 \mathrm{mM}$, and it was found that $5 \mathrm{mM}$ gave the best photocatalytic performance with the highest initial reaction rate (Table 1). 
Table 1. Photocatalytic activity (initial reaction rate, $\mathrm{r}_{0}$, evolved hydrogen and oxygen at $7 \mathrm{~h}$ ) of the series of ferric aqueous solutions (initial $\mathrm{Fe}^{3+}$ concentration, $\left.\mathrm{C}_{0}\right)$ under study, using $\mathrm{Au}(0.25 \mathrm{wt} \%) / \mathrm{TiO}_{2}$ and $\mathrm{Au}(0.25 \mathrm{wt} \%) / \mathrm{CeO}_{2}$ for hydrogen and oxygen generation, respectively.

\begin{tabular}{|c|c|c|c|c|}
\hline $\begin{array}{c}\mathrm{C}_{0} \mathrm{Fe}^{3+} \\
(\mathrm{mM})\end{array}$ & $\begin{array}{l}\text { Evolved } \mathrm{H}_{2,7 \mathrm{~h}} \\
\quad(\mu \mathrm{mol})\end{array}$ & $\begin{array}{l}\text { Evolved } O_{2,7 h} \\
\quad(\mu \mathrm{mol})\end{array}$ & $\begin{array}{c}\mathrm{H}_{2} \mathrm{r}_{0} \times 10^{2} \\
\left(\mu \mathrm{mol} \cdot \mathrm{min}^{-1}\right)\end{array}$ & $\begin{array}{c}\mathrm{O}_{2} \mathrm{r}_{0} \times 10^{2} \\
\left(\mu \mathrm{mol} \cdot \mathrm{min}^{-1}\right)\end{array}$ \\
\hline 2 & 56.2 & 28.1 & 34.2 & 20.7 \\
\hline 5 & 166.1 & 75.6 & 114.0 & 53.4 \\
\hline 10 & 86.2 & 43.0 & 96.3 & 32.5 \\
\hline 20 & 43.2 & 24.2 & 34.8 & 21.1 \\
\hline 50 & 25.5 & 16.3 & 33.4 & 23.5 \\
\hline
\end{tabular}

$\mathrm{Au} / \mathrm{CeO}_{2}$ was selective for oxygen generation as it was found to be unable to generate hydrogen. The reason for this behavior might be related to the energy of the electrons in the conduction band of $\mathrm{Au} / \mathrm{CeO}_{2}$, which was not sufficient for water reduction (see Figure 1). In contrast, these electrons were able to reduce $\mathrm{Fe}^{3+}$ to $\mathrm{Fe}^{2+}$.

The influence of gold on the photocatalytic performance of the Z-scheme overall water splitting by $\mathrm{TiO}_{2}$ and $\mathrm{CeO}_{2}$ was determined by comparing the photocatalytic activity of the gold-containing semiconductors in comparison with the same semiconductors without gold (Figure 5).

As expected, despite the irradiation source used not permitting exclusively visible-light emission, a positive effect of the presence of gold was observed.

The gold loading plays an important role in the photocatalytic efficiency of the system. To demonstrate this point, we performed some photocatalytic tests with equal gold loading on titania and ceria varying from 0.25 to $1.0 \mathrm{wt} \%$. By measuring the initial rate of hydrogen generation, it was concluded that the optimum gold loading under these conditions was the lowest $(0.25 \mathrm{wt} \%)$ (Table 2$)$.

Table 2. Photocatalytic activity (initial reaction rate, $\mathrm{r}_{0}$, evolved hydrogen and oxygen at $7 \mathrm{~h}$ ) of the series of gold-containing samples under study, using a $5 \mathrm{mM}$ ferric solution and $\mathrm{TiO}_{2}$ and $\mathrm{CeO}_{2}$ as photocatalysts for hydrogen and oxygen generation, respectively.

\begin{tabular}{|c|c|c|c|c|}
\hline $\begin{array}{l}\text { Au Loading } \\
\text { (wt } \%)\end{array}$ & $\begin{array}{c}\text { Evolved } \mathrm{H}_{2,7 \mathrm{~h}} \\
\quad(\mu \mathrm{mol})\end{array}$ & $\begin{array}{l}\text { Evolved } O_{2,7 h} \\
\quad(\mu \mathrm{mol})\end{array}$ & $\begin{array}{c}\mathrm{H}_{2} \mathrm{r}_{0} \times 10^{2} \\
\left(\mu \mathrm{mol} \cdot \mathrm{min}^{-1}\right)\end{array}$ & $\begin{array}{c}\mathrm{O}_{2} \mathrm{r}_{0} \times 10^{2} \\
\left(\mu \mathrm{mol} \cdot \mathrm{min}^{-1}\right)\end{array}$ \\
\hline 0.25 & 166.1 & 75.6 & 114.0 & 53.4 \\
\hline 0.6 & 152.0 & 61.3 & 112.1 & 70.8 \\
\hline 1.0 & 71.0 & 25.1 & 67.0 & 32.2 \\
\hline
\end{tabular}

$\mathrm{Au}$ content in the aqueous reacting environment after the reaction was below the detection limit (0.1 ppm).

In a precedent work it was also observed that Au loading is a key parameter controlling the photocatalytic activity of $\mathrm{Au} / \mathrm{TiO}_{2}$ and that an optimal Au percentage exists. Since the presence of $\mathrm{Au}$ nanoparticles is detrimental for the efficiency of $\mathrm{TiO}_{2}$ photocatalysis under UV irradiation, but enhances the photocatalytic efficiency for visible-light irradiation, the observed beneficial effect of Au might be explained considering that, by operating under our conditions, visible light gave the largest contribution to the total photocatalytic water splitting. In view of the above data, we propose the water-splitting mechanism shown in Figure 6.

Upon light absorption (mostly visible), electrons (in the conduction band) and holes (in the valence band) were generated in $\mathrm{Au} / \mathrm{CeO}_{2}$. It was found that electrons in $\mathrm{Au} / \mathrm{CeO}_{2}$ were inefficient to generate hydrogen and, therefore, they were captured by $\mathrm{Fe}^{3+}$, forming $\mathrm{Fe}^{2+}$ ions that diffused through the Nafion membrane to the $\mathrm{Au} / \mathrm{TiO}_{2}$ cell. The holes located on $\mathrm{Au}$ of the $\mathrm{Au} / \mathrm{CeO}_{2}$ photocatalyst had sufficient oxidation power to generate oxygen via water oxidation as previously proven [42]. In the $\mathrm{Au} / \mathrm{TiO}_{2}$ cell, similar charge separation as in the $\mathrm{Au} / \mathrm{CeO}_{2}$ cell would occur upon photon absorption; however, in this case, the reduction potential of the $\mathrm{TiO}_{2}$ conduction band had enough energy to form 
hydrogen via water reduction. The holes on Au were, in this case, quenched by oxidation of $\mathrm{Fe}^{2+}$ diffusing through the Nafion membrane from the $\mathrm{Au} / \mathrm{CeO}_{2}$ cell.

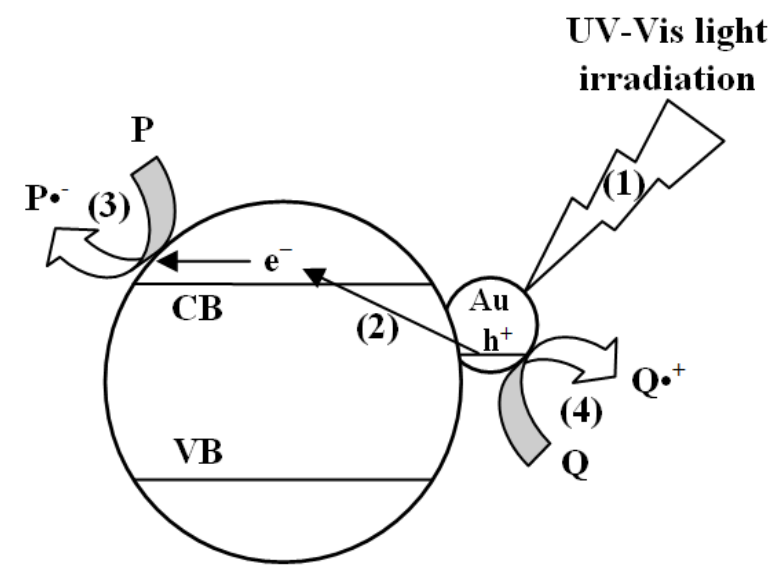

Figure 6. Elementary steps occurring in the photocatalytic reaction upon irradiation of a gold-containing photocatalyst sample under ultraviolet (UV) irradiation: (1) photon absorption; (2) electron migration from $\mathrm{Au}$ to semiconductor conduction band; (3) electron quenching by P;

(4) $\mathrm{Q}$ oxidation by $\mathrm{H}^{+}$mediated by Au.

To demonstrate the photocatalytic activity of the pair $\mathrm{Au} / \mathrm{TiO}_{2}$ and $\mathrm{Au} / \mathrm{CeO}_{2}$ for the overall water splitting through a Z-scheme under visible light, analogous photocatalytic experiments were performed by filtering light to almost completely remove the irradiation wavelength below $400 \mathrm{~nm}$ (Figure 7). Under these conditions, the irradiance decreased from $2133 \mathrm{~mW} \cdot \mathrm{m}^{-2}$ to $570 \mathrm{~mW} \cdot \mathrm{m}^{-2}$. In Figure 7, the two regimes previously observed in Figure 5 were not present. This can be ascribed to the lower irradiance (3.6 times lower for the visible light compared to UV irradiation), which decreased the $\mathrm{H}_{2} / \mathrm{O}_{2}$ generation rate (slopes of $0.08 \mu \mathrm{mol}_{\mathrm{H} 2} \cdot \mathrm{min}^{-1}$ and $0.04 \mu \mathrm{mol}_{\mathrm{O} 2} \cdot \mathrm{min}^{-1}$ ), thus requiring a lower $\mathrm{Fe}^{2+}$ ion diffusion rate.

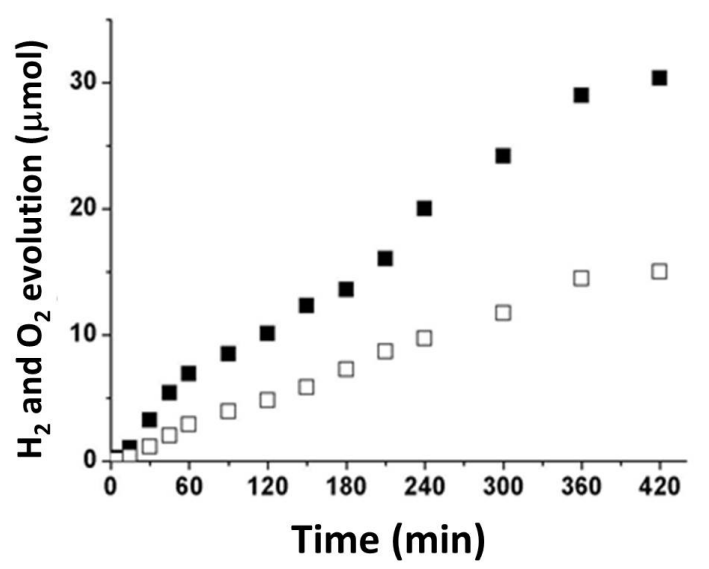

Figure 7. Hydrogen production ( $\square$ ) using $\mathrm{Au}(0.25 \mathrm{wt} \%) / \mathrm{TiO}_{2}$ and oxygen production $(\square)$ using $\mathrm{Au}$ $(0.25 \mathrm{wt} \%) / \mathrm{CeO}_{2}$, under visible-light irradiation (initial $\mathrm{Fe}^{3+}$ concentration was $5 \mathrm{mM}$ in the $\mathrm{Au} / \mathrm{CeO}_{2}$ cell and initial $\mathrm{Fe}^{2+}$ concentration was zero in the $\mathrm{Au} / \mathrm{TiO}_{2}$ cell).

Also under these conditions, hydrogen and oxygen generation was observed in stoichiometric amounts in the $\mathrm{Au} / \mathrm{TiO}_{2}$ and $\mathrm{Au} / \mathrm{CeO}_{2}$ cells, respectively (Table 3). 
Table 3. Photocatalytic activity (initial reaction rate, $\mathrm{r}_{0}$, evolved hydrogen and oxygen at $7 \mathrm{~h}$ ) of the $\mathrm{Au}$ $(0.25 \mathrm{wt} \%) / \mathrm{TiO}_{2}$ and $\mathrm{Au}(0.25 \mathrm{wt} \%) / \mathrm{CeO}_{2}$ samples using a $5 \mathrm{mM}$ ferric solution for hydrogen and oxygen generation, respectively, under visible-light irradiation.

\begin{tabular}{|c|c|c|c|c|}
\hline $\begin{array}{l}\text { Au Loading } \\
\text { (wt } \%)\end{array}$ & $\begin{array}{l}\text { Evolved } \mathrm{H}_{2,7 \mathrm{~h}} \\
\quad(\mu \mathrm{mol})\end{array}$ & $\begin{array}{l}\text { Evolved } O_{2,7 h} \\
\quad(\mu \mathrm{mol})\end{array}$ & $\begin{array}{c}\mathrm{H}_{2} \mathrm{r}_{0} \times 10^{2} \\
\left(\mu \mathrm{mol} \cdot \mathrm{min}^{-1}\right)\end{array}$ & $\begin{array}{c}\mathrm{O}_{2} \mathrm{r}_{0} \times 10^{2} \\
\left(\mu \mathrm{mol} \cdot \mathrm{min}^{-1}\right)\end{array}$ \\
\hline 0.25 & 30.36 & 14.89 & 11.0 & 4.2 \\
\hline
\end{tabular}

\section{Conclusions}

In the present article, we combined the high activity of $\mathrm{Au} / \mathrm{TiO}_{2}$ to photocatalytically generate hydrogen with the high activity of $\mathrm{Au} / \mathrm{CeO}_{2}$ to promote oxygen evolution from water. Thus, overall water splitting was obtained by operating through a Z-scheme using a Nafion membrane and $\mathrm{Fe}^{3+} / \mathrm{Fe}^{2+}$ as an electrolyte.

The obtained results showed the following:

- The employed photocatalysts promoted simultaneous hydrogen and oxygen generation;

- The optimal content of ferric ions in the $\mathrm{Au} / \mathrm{CeO}_{2}$ compartment was $5 \mathrm{mM}$;

- Gold operated as a photosensitizer allowing photocatalytic hydrogen and oxygen formation under visible light;

- A gold loading of $0.25 \mathrm{wt} \%$ led to the best results in terms of hydrogen and oxygen evolution (166.1 and $75.6 \mu \mathrm{mol}$, respectively, after $7 \mathrm{~h}$ of UV-visible-light irradiation);

- Hydrogen and oxygen were produced in stoichiometric amounts, i.e., 30.36 and $14.89 \mu \mathrm{mol}$, respectively, after $7 \mathrm{~h}$ of irradiation with visible light;

- The decrease in permeation rate of iron ions through the Nafion membrane affected the photocatalytic performance, slowing the generation rates of both hydrogen and oxygen.

Author Contributions: T.M. and R.M. conceived and designed the experiments; T.M. performed the experiments; T.M., R.M., P.A. and A.M. analyzed the data; R.M. and P.A. contributed reagents/materials/analysis tools; T.M., R.M., P.A., A.M., A.F. wrote the paper.

Funding: This research received no external funding.

Conflicts of Interest: The authors declare no conflicts of interest.

\section{References}

1. Bamwenda, G.R.; Tsubota, S.; Nakamura, T.; Haruta, M. Photoassisted Hydrogen-Production from a water-ethanol solution-A Comparison of activities of $\mathrm{Au}-\mathrm{TiO}_{2}$ and $\mathrm{Pt}-\mathrm{TiO}_{2}$. J. Photochem. Photobiol. A-Chem. 1995, 89, 177-189. [CrossRef]

2. Khan, S.U.M.; Al-Shahry, M.; Ingler, W.B. Efficient photochemical water splitting by a chemically modified n- $\mathrm{TiO}_{2}$. Science 2002, 297, 2243-2245. [CrossRef] [PubMed]

3. Loddo, V.; Palmisano, L.; Marino, T.; Molinari, R. Membranes for photocatalysis in water and wastewater treatment. In Advanced Membrane Science and Technology for Sustainable Energy and Environmental Applications; Basile, A., Nunes, S.P., Eds.; Woodhead Publishing: Sawston, UK, 2011; pp. 746-768.

4. Maeda, K.; Domen, K. New non-oxide photocatalysts designed for overall water splitting under visible light. J. Phys. Chem. C 2007, 111, 7851-7861. [CrossRef]

5. Li, D.; Yu, J.C.; Nguyen, V.; Wu, C.S.; Wang, X. A dual-function photocatalytic system for simultaneous separating hydrogen from water splitting and photocatalytic degradation of phenol in a twin-reactor. Appl. Catal. B Environ. 2018, 239, 268-279. [CrossRef]

6. Argurio, P.; Fontananova, E.; Molinari, R.; Drioli, E. Photocatalytic Membranes in Photocatalytic Membrane Reactors. Processes 2018, 6, 162. [CrossRef]

7. Iglesias, O.; Rivero, M.J.; Urtiaga, A.M.; Ortiz, I. Membrane-based photocatalytic systems for process intensification. Chem. Eng. J. 2016, 305, 136-148. [CrossRef] 
8. Rahimpour, M.R.; Mahmoodi, L. Performance of Reactors With PMs; Elsevier Inc.: Amsterdam, The Netherlands, 2018; ISBN 9780128135495.

9. Molino, A.; Migliori, M.; Blasi, A.; Davoli, M.; Marino, T.; Chianese, S.; Catizzone, E.; Giordano, G. Municipal waste leachate conversion via catalytic supercritical water gasification process. Fuel 2017, 206, 155-161. [CrossRef]

10. Marbán, G.; Valdés-Solís, T. Towards the hydrogen economy? Int. J. Hydrog. Energy 2007, 32, $1625-1637$. [CrossRef]

11. Armaroli, N.; Balzani, V. The hydrogen issue. ChemSusChem 2011, 4, 21-36. [CrossRef]

12. Ball, M.; Wietschel, M. The future of hydrogen-Opportunities and challenges. Int. J. Hydrog. Energy 2009, 34, 615-627. [CrossRef]

13. Fujishima, A.; Honda, K. Electrochemical photolysis of water at a semiconductor electrode. Nature 1972, 238, 37-38. [CrossRef] [PubMed]

14. Silva, C.G.; Juárez, R.; Marino, T.; Molinari, R.; García, H. Influence of excitation wavelength (UV or visible light) on the photocatalytic activity of titania containing gold nanoparticles for the generation of hydrogen or oxygen from water. J. Am. Chem. Soc. 2011, 133, 595-602. [CrossRef] [PubMed]

15. Galiano, F.; Song, X.; Marino, T.; Boerrigter, M.; Saoncella, O.; Simone, S.; Faccini, M.; Chaumette, C.; Drioli, E.; Figoli, A. Novel Photocatalytic PVDF/Nano-TiO 2 Hollow Fibers for Environmental Remediation. Polymers 2018, 10, 1134. [CrossRef]

16. Molinari, R.; Caruso, A.; Palmisano, L. Photocatalytic Processes in Membrane Reactors. In Comprehensive Membrane Science and Engineering; Drioli, E., Giorno, L., Eds.; Elsevier Science B.V.: Oxford, UK, 2010; Volume 3, pp. 165-193, ISBN 9780080932507.

17. Hoffmann, M.R.; Martin, S.T.; Choi, W.; Bahnemann, D.W. Environmental Applications of Semiconductor Photocatalysis. Chem. Rev. 1995, 95, 69-96. [CrossRef]

18. Schneider, J.; Matsuoka, M.; Takeuchi, M.; Zhang, J.; Horiuchi, Y.; Anpo, M.; Bahnemann, D.W. Understanding $\mathrm{TiO}_{2}$ Photocatalysis: Mechanisms and Materials. Chem. Rev. 2014, 114, 9919-9986. [CrossRef] [PubMed]

19. Kudo, A.; Miseki, Y. Heterogeneous photocatalyst materials for water splitting. Chem. Soc. Rev. 2009, 38, 253-278. [CrossRef] [PubMed]

20. Marino, T.; Boerigter, M.; Faccini, M.; Chaumette, C.; Arockiasamy, L.; Bundschuh, J.; Figoli, A. Photocatalytic activity and synthesis procedures of $\mathrm{TiO}_{2}$ nanoparticles for potential applications in membranes. In Application of Nanotechnology in Membranes for Water Treatment; Hoinkis, J., Figoli, A., Altinkaya, S.A., Bundschuh, J., Eds.; CRC, Taylor and Francis Group: Boca Raton, FL, USA, 2017; ISBN 9781138896581.

21. Figoli, A.; Marino, T.; Simone, S.; Boerighter, M.; Faccin, M.; Chaumette, C.; Drioli, E. Application of nano-sized $\mathrm{TiO}_{2}$ in membrane technology. In Application of Nanotechnology in Membranes for Water Treatment; Hoinkis, J., Figoli, A., Altinkaya, S.A., Bundschuh, J., Eds.; CRC, Taylor and Francis Group: Boca Raton, FL, USA, 2017; ISBN 9781138896581.

22. Fujishima, A.; Rao, T.N.; Tryk, D.A. Titanium dioxide photocatalysis. J. Photochem. Photobiol. C Photochem. Rev. 2000, 1, 1-21. [CrossRef]

23. Kumar, S.G.; Devi, L.G. Review on modified $\mathrm{TiO}_{2}$ photocatalysis under UV/visible light: Selected results and related mechanisms on interfacial charge carrier transfer dynamics. J. Phys. Chem. A 2011, 115, 13211-13241. [CrossRef]

24. Primo, A.; Marino, T.; Corma, A.; Molinari, R.; Garcia, H. Efficient visible-light photocatalytic water splitting by minute amounts of gold supported on nanoparticulate $\mathrm{CeO}_{2}$ obtained by a biopolymer templating method. J. Am. Chem. Soc. 2011, 133, 6930-6933. [CrossRef]

25. Marino, T.; Primo, A.; Corma, A.; Molinari, R.; Garcia, H. Photocatalytic overall water splitting by combining gold nanoparticles supported on $\mathrm{TiO}_{2}$ and $\mathrm{CeO}_{2}$. In Proceedings of the 2nd European Symposium on Photocatalysis, Bordeaux, France, 19 October 2011; p. 76.

26. Higashi, M.; Abe, R.; Ishikawa, A.; Takata, T.; Ohtani, B.; Domen, K. Z-scheme Overall Water Splitting on Modified-TaON Photocatalysts under Visible Light $(\lambda<500 \mathrm{~nm})$. Chem. Lett. 2008, 37, 138-139. [CrossRef]

27. Maeda, K.; Higashi, M.; Lu, D.; Abe, R.; Domen, K. Efficient nonsacrificial water splitting through two-step photoexcitation by visible light using a modified oxynitride as a hydrogen evolution photocatalyst. J. Am. Chem. Soc. 2010, 132, 5858-5868. [CrossRef] [PubMed] 
28. Chiarello, G.L.; Tealdi, C.; Mustarelli, P.; Selli, E. Fabrication of Pt/Ti/ $\mathrm{TiO}_{2}$ Photoelectrodes by RF-Magnetron Sputtering for Separate Hydrogen and Oxygen Production. Materials 2016, 9, 279. [CrossRef] [PubMed]

29. Selli, E.; Chiarello, G.L.; Quartarone, E.; Mustarelli, P.; Rossetti, I.; Forni, L. Photocatalytic water splitting device for separate hydrogen and oxygen evolution. Chem. Commun. 2007, 47, 5022-5024. [CrossRef] [PubMed]

30. Xu, Q.; Zhang, L.; Yu, J.; Wageh, S.; Al-ghamdi, A.A.; Jaroniec, M. Direct Z-scheme photocatalysts: Principles, synthesis, and applications. Mater. Today 2018, 21, 1042-1063. [CrossRef]

31. Lo, C.; Huang, C.; Liao, C.; Wu, J.C.S. Novel twin reactor for separate evolution of hydrogen and oxygen in photocatalytic water splitting. Int. J. Hydrog. Energy 2010, 35, 1523-1529. [CrossRef]

32. Seger, B.; Kamat, P.V. Fuel cell geared in reverse: Photocatalytic hydrogen production using a $\mathrm{TiO}_{2} / \mathrm{Nafion} / \mathrm{Pt}$ membrane assembly with no applied bias. J. Phys. Chem. C 2009, 113, 18946-18952. [CrossRef]

33. Yu, S.-C.; Huang, C.-W.; Liao, C.-H.; Wu, J.C.S.; Chang, S.-T.; Chen, K.-H. A novel membrane reactor for separating hydrogen and oxygen in photocatalytic water splitting. J. Membr. Sci. 2011, 382, 291-299. [CrossRef]

34. Kitano, M.; Tsujimaru, K.; Anpo, M. Decomposition of water in the separate evolution of hydrogen and oxygen using visible light-responsive $\mathrm{TiO}_{2}$ thin film photocatalysts: Effect of the work function of the substrates on the yield of the reaction. Appl. Catal. A Gen. 2006, 314, 179-183. [CrossRef]

35. Fujihara, K.; Ohno, T.; Matsumura, M. Splitting of water by electrochemical combination of two photocatalytic reactions on $\mathrm{TiO}_{2}$ particles. J. Chem. Soc. Faraday Trans. 1998, 94, 3705-3709. [CrossRef]

36. Kraytsberg, A.; Yair, E.-E. Review of Advanced Materials for Proton Exchange Membrane Fuel Cells. Energy Fuels 2014, 28, 7303-7330. [CrossRef]

37. Ramírez, J.; Godínez, L.A.; Méndez, M.; Meas, Y.; Rodriguez, F.J. Heterogeneous photo-electro-Fenton process using different iron supporting materials. J. Appl. Electrochem. 2010, 40, 1729-1736. [CrossRef]

38. Feng, J.; Hu, X.; Yue, P.L.; Zhu, H.Y.; Lu, G.Q. Discoloration and mineralization of Reactive Red HE-3B by heterogeneous photo-Fenton reaction. Water Res. 2003, 37, 3776-3784. [CrossRef]

39. Sabhi, S.; Kiwi, J. Degradation of 2,4-dichlorophenol by immobilized iron catalysts. Water Res. 2001, 35, 1994-2002. [CrossRef]

40. Kiwi, J. Innovative immobilized Fenton systems useful in the abatement of industrial pollutants. In Proceedings of the Third Asia-Pacific Conference on Sustainable Energy and Environmental Technologies, Hong Kong, China, 3-6 December 2000; p. 562.

41. Goswami, A.K.; Acharya, A.; Pandey, A.K. Study of self-diffusion of monovalent and divalent cations in Nafion-117 ion-exchange membrane. J. Phys. Chem. B 2001. [CrossRef]

42. Silva, C.G.; Bouizi, Y.; Fornés, V.; Garcia, H. Layered Double Hydroxides as Highly Efficient Photocatalysts for Visible Light Oxygen Generation from Water. J. Am. Chem. Soc. 2009, 131, 13833-13839. [CrossRef] [PubMed]

(C) 2019 by the authors. Licensee MDPI, Basel, Switzerland. This article is an open access article distributed under the terms and conditions of the Creative Commons Attribution (CC BY) license (http://creativecommons.org/licenses/by/4.0/). 